\title{
Science and Arts Streams Students' Scientific Epistemological Beliefs
}

\author{
Yong Xiu Hui ${ }^{1} \&$ Fatin Aliah Phang ${ }^{1}$ \\ ${ }^{1}$ Faculty of Education, Universiti Teknologi Malaysia Johor Bahru, Malaysia \\ Correspondence: Fatin Aliah Phang, Faculty of Education, Universiti Teknologi Malaysia, 81310 Johor, \\ Malaysia. Tel: 607-553-4557. E-mail: p-fatin@utm.my
}

Received: November 7, 2014 Accepted: March 17, 2015 Online Published: June 28, 2015

doi:10.5539/ies.v8n13p88

URL: http://dx.doi.org/10.5539/ies.v8n13p88

\begin{abstract}
As a step to realize Vision 2020, 60:40 ratio policy was announced to produce manpower from scientific and technical field. However, the number of students channel into science stream classes is still far from the targeted ratio. The deterioration of the students enroll into science stream after PMR, Lower Secondary Assessment will give an impact to the effort in encouraging them to further science study in tertiary level. The aim of the study is to identify scientific epistemological belief among science stream and arts stream students. Besides, it is also to identify the difference of scientific epistemological belief between science stream and arts stream students. A total of 370 respondents were selected from both science and arts streams to answer the questionnaire Physics Scientific Epistemological Measurement for Students (PESP). Results showed that most of the science stream respondents were in transition scientific epistemological belief level (67.39\%). In the case of arts stream respondents, most of the respondents were in naïve and low transition epistemological belief level (92.5\%). Overall, the mean value for scientific epistemological belief of science stream respondents (3.14) is higher compared to arts stream respondents (3.01). Based on the t- test result, there is a significance difference in scientific epistemological belief for both science stream and arts stream respondents $(\mathrm{t}=.07909-.17289, \mathrm{p}<0.05)$. The research results draw implications to the current curriculum system. Duration of science classes, instructions, examination questions' pattern and curricular materials should be examined and amended for the current needs. However, more research should be carried out in order to improve students' scientific epistemological belief level.
\end{abstract}

Keywords: scientific epistemological belief level, science stream, physics scientific epistemological measurement for students

\section{Introduction}

In 1991, Tun Dr. Mahathir Mohammad, Malaysia fourth Prime Minister declared the Vision 2020 in Malaysia Business Council inaugural meeting. As a step to realize Vision 2020, 60:40 ratio policy was announced to produce manpower from scientific and technical field. However, the number of students channel into science stream classes is still far from the targeted ratio (Ong, 2006; Mohd-Salleh et al., 2012).

The decline in the quality of the ration of students enrols into science stream after PMR will give an impact to the effort in encouraging them to further science study in tertiary level (Alimuddin, 2012). The causes of the deterioration might be difficulty level of the subject (Checkley, 2010) and interest (Varghese, 2006). However, researches conducted by Checkley (2010), Caygill and Telford (2007), Zanaton, Lilia, and Kamisah (2006) showed that students perceive science subject as an interesting and not a difficult subject to learn. This deterioration of science stream students is in contrary to the headings science curriculum (MOE, 2005). As a developing country, we need professional such as researchers, scientists, and engineers to motivate the economy development (Phang et al., 2011; Phang et al., 2013). For the sake of economy growth, science stream is the only manufacturer to produce science manpower in order meets the nation's professional demands. Hence, the reasons of declining trend in science stream classes should be identified. Research conducted by Checkley (2005) showed students' choices are greatly influenced by their perception. Harteis, Gruber, and Hertramph (2010) reported that the perception of learning opportunities was affected by one's epistemological belief. Hence, epistemological belief might be the factor which influences students' choices of science stream or arts stream classes.

Epistemological belief is defined as students' thinking about knowledge, the definition about knowledge, how 
knowledge is constructed, how is it evaluated and know where it occurs (Hofer, 2011). A research carried out by Trautwein and Ludtke (2007) found that students' epistemological beliefs in certainty of knowledge give impact on students' choices of study at college level. Furthermore, Liu and Tsai (2008) reported that the difference of epistemological belief is present among science and non-science major students. Again, students' epistemological belief might affect their choices in major field.

The aim of the study is to identify scientific epistemological belief among science stream and arts stream students. Besides, it is also to identify the difference of scientific epistemological belief between science stream and arts stream students. There are many research have showed that students showing positive attitude, and feeling interested in learning science subject. Trautwein and Ludtke (2007) reported that student's scientific epistemological belief will impact their choices of major in college level. Therefore, it will be important to find out form 4 students' scientific epistemological belief so that educator able to take action to improve students' scientific epistemological belief.

\section{Method}

There are 370 respondents were selected from both science and arts stream to answer the questionnaire Physics Scientific Epistemological Measurement for Students (PESP) which is constructed by Nor (2013). Questionnaire PESP was constructed based on several instruments used in the previous research. There were 45 items used to examine students' scientific epistemological beliefs. This instrument was divided into three sections which were sections A, B and C. Section A was a demographical questionnaire. This section consisted of six items investigating student's school name, class, gender, races, their PMR results in subject science and mathematics. Besides, information about which science subject they are taking was collected. If student is taking at least two science subjects then the student will be considered as science stream students (BPPD, 2000).

There were 45 items which examined students' scientific epistemological beliefs in section B and C. In section B, 11 items were examined. Five point CAD (Contrasting Alternatives Design) rather than Likert scale was used in this section (Nor, 2013). This is because according to Azizi et al. (2007), Likert scale was much more suitable in measuring students' attitude. On the other hand, as explained by Halloun (2001), the use of CAD avoids students from confusing with the option provided in the questionnaires. For example, the choice of strongly disagree (SD) and disagree (D) or agree (A) and strongly agree (SA).

There were 34 items in section C. The difference in between section B and C was the usage of Likert scale in this section C. Students were required to rate the items by using five point Likert scale in section C. The five point Likert scale used in section B was Strongly Disagree (SD), Disagree (D), Somewhat Disagree (S), Agree (A) and Strongly Agree (SA). A high Alpha Cronbach value which is 0.971 was obtained.

Two types of analysis were used which were descriptive statistic and inferential statistic. Sections B and C, ordinal scale was applied. The item consisted of both positive and negative items. Hence, researcher examined students' responds manually. Besides, students' responds was classified into three categories which were responds which are opposite with scientist, responds which is less agree with scientist and responds same as scientist. Then, according to the number of item in each classification, researcher grouped them into 4 categories of scientific epistemological beliefs levels. The researcher keyed in students' scientific epistemological beliefs into SPSS system. Descriptive data analysis was used to describe students' responds to each item in term of mean and standard deviation (Nor, 2013).

There were ten hypotheses testing in this research study in order to answer research objective. Inferential data analysis was carried out in the hypothesis testing part. One sample t-test was applied to in the hypothesis testing part. The test was conducted at the level of significance, 0.05 . If calculated $\mathrm{p}$ value is greater than $0.05, \mathrm{H} 0$ would be retained and vice versa.

\section{Results}

According to the obtained result in table 1, we found out that most of the science stream respondents are in transition scientific epistemological belief level. Besides, a significant number of science stream respondents are in naïve epistemological belief level. On the other hand, the number of science stream respondents in sophisticated epistemological belief level is low. In the case of arts stream respondents, most of the arts stream respondents are in naïve and low transition epistemological belief level. However, few number of arts stream respondents in high transition and sophisticated scientific epistemological belief level. The percentage of arts stream respondents in high transition and sophisticated epistemological belief level is low compared to science stream respondents.

Overall, the mean value for scientific epistemological belief of science stream respondents is higher 
compared to arts stream respondents. Based on the t- test result, there is a significance difference in scientific epistemological belief for both science stream and arts stream respondents $(t=.07909-.17289, \mathrm{p}<$ 0.05). Further, a detailed analysis revealed that science stream respondents showed better understanding in the dimension of application of physics concept in daily life, source of knowledge, theories and laws are different forms of scientific knowledge and based upon observation and inferences compared to arts stream respondents. Conversely, arts stream respondents showed better understanding in the dimension of the process to knowledge production compared to science stream respondent. On the other hand, both science and arts stream respondents showed no difference in the dimension of mathematics in physics, tentative, creative and myth of scientific method. The result might reveal the reason why respondents choose to be enrolled into science or arts stream. The reason is self- selection (Trautwein \& Ludtke, 2006). Self-selection is belief in certainty dimension choose to study hard field (pure science and engineering). According to our data analysis, 57\% science stream respondents showed opposite view as scientist in dimension of the process to knowledge production. Research conducted by Paulson \& Wells (1998) revealed that students in hard field have naïve epistemological belief in certainty of knowledge than soft science. Therefore, we belief that self-selection might affect students' choices to be enrolled into science or arts stream. Based on the obtained results, a correct scientific epistemological belief should be exposed to students as early as in primary school. This can be done by changing teacher's teaching methods and the assessment to assess students' performance in subject science.

Table 1. Comparison between science stream arts stream respondents in each scientific epistemological belief level

\begin{tabular}{llllll}
\hline \multicolumn{6}{l}{ Scientific epistemological belief level } \\
\hline Epistemological belief & Naïve & Low transition & High Transition & Sophisticated & Total \\
\hline \multirow{2}{*}{ Science stream } & 52 & 94 & 30 & 8 & 184 \\
& $(28.3 \%)$ & $(51.1 \%)$ & $(16.3 \%)$ & $(4.3 \%)$ & $(49.7 \%)$ \\
\multirow{2}{*}{ Art stream } & 97 & 75 & 12 & 2 & 186 \\
& $(52.2 \%)$ & $(40.3 \%)$ & $(6.5 \%)$ & $(1.1 \%)$ & $(50.3 \%)$ \\
Total & 149 & 169 & 42 & 10 & 370 \\
& $(40.3 \%)$ & $(45.7 \%)$ & $(11.4 \%)$ & $(2.7)$ & $(100.0 \%)$ \\
\hline
\end{tabular}

\section{Discussion and Conclusion}

The issue of deterioration of science stream respondents gave us an idea to identify scientific epistemological belief among the science stream and arts stream respondents. This study was conducted with students in Johor Bahru area who enrolled into form 4 in year 2014. Their scientific epistemological belief level was identified. Most of the science stream students were in transition scientific epistemological belief level which is considered as mixed view (Halloun, 2001). On the other hand, most of the arts stream respondents were in naïve and low transition epistemological belief level. There is a significance difference in between science stream and arts stream respondents in scientific epistemological belief level. Based on the result, science stream respondents hold better scientific epistemological belief than arts stream respondents.

Although both streams of students showed differences in scientific epistemological belief, the existed difference was low. Besides, science stream respondents do not show sophisticated epistemological belief in all scientific epistemology dimensions. Furthermore, both streams of students showed no difference in 4 dimension which are mathematics in physics, tentative, creative and myth of scientific method.

On the other hand, science stream students showed better scientific epistemological belief than arts stream respondents in 4 dimensions which are application of physics in daily life, the source of knowledge, theories and laws are different forms of science knowledge and based upon observation and inferences. These 4 dimensions might be the reason of why students choose to be enrolled into science stream. Besides, arts stream respondents have better understanding than science stream respondents in the dimension of the process to knowledge production. Research conducted by Smith and Wenk (2006) reported that students who believe in certainty will lead them to science stream. Therefore it is accepted that science stream respondents have naive epistemological belief level in process to knowledge production and this dimension did play a role in affecting students' choices 
of stream. The reason of self-selection (Trautwein \& Ludtke, 2006) was used to explain the situation. On the other hand, students' scientific epistemological belief was closely related with academic result. Paulson \& Wells (1998) reported that students with higher academic result were less likely believe in simple knowledge. Hence, naive scientific epistemological belief causes students to be enrolled into arts stream.

According to the t-test result, it showed that there is a significant difference between science stream and arts stream respondents in scientific epistemological belief level. This result is in line with the research conducted by Kurt (2009) and Takoyashi, Piti, and Brian (2012). They reasoned that duration of science classes might affect repondents' scientific epistemological beliefs. Peer and Atputhasamy (2005) showed that eight graders respondents have lowest scores in the dimension of justification and development. This is due to the reason of the way of using science experiment in science classroom. Hence, instructions, examination questions' pattern and curricular materials should be examined and amended for the current needs. However, more research should be done on the topic of scientific epistemological belief in order to improve students' scientific epistemological belief level. Based on the discussion, researcher found out that duration of science classes, curricular materials and the way of using experiments affects students' scientific epistemological belief. As a result, different scientific epistemological belief was existed between science and arts stream students. Hence, it can be concluded that students' scientific epistemological belief affects students' choices to be enrolled into science or arts stream.

\section{Acknowledgements}

The research is funded by the Fundamental Research Grant Scheme of RM 60,000.00 granted by the Ministry of Education Malaysia and managed by Universiti Teknologi Malaysia. With the support, I have the opportunity to see the breadth of research which is ongoing in various fields.

\section{References}

Abd-El-Khalick, F., Mindy, W., \& Le, A. P. (2008). Representations of Nature of Science in High School Chemistry Textbooks over the Past Four Decades. Journal of Research in Science Teaching, 45(7), 835-855. http://dx.doi.org/10.1002/(SICI)1098-237X(199807)82:4<417::AID-SCE1>3.0.CO;2-E

Abd-El-Khalick, F., Randy, L. B., \& Lederman, N. G. (1998). The Nature of Science and Instructional Practice: Making the Unnatural Natural. Science Education, 82(4), 418-436. http://dx.doi.org/10.1002/tea.20226

Halloun, I. (2001). Students Views about Science: A Comparative Survey. Beirut: Phoenix Series/Educational Research Centre, Lebanese University.

Hofer, B. K. (2001). Personal Epistemology Research: Implications for Learning and Teaching. Journey of Educational Psychology Review, 13(4), 353-383. http://dx.doi.org/10.1023/A:1011965830686

Krejcie, R. V., \& Morgan, D. W. (1970). Determining Sample Size for Research Activities. Educational and Psychological Measurement, 30, 607-610.

Kurt, F. (2009). Investigating Students Epistemology Beliefs Through Gender, Grade Level, and Fields of the Study (Master of Science, The Middle East Technical University, Turkey).

Liu, S. Y., \& Tsai, C. C. (2008). Differences in the Scientific Epistemological Views of Undergraduate Students. $\begin{array}{llll}\text { International Journal of Science } & \text { Education, }\end{array}$ http://dx.doi.org/10.1080/09500690701338901

Mohd-Salleh, A., Phang, F. A., Mohamad, B. A., \& Salmiza, S. (2012). Science education policy in Malaysia. In L. M. Tahir, \& H.Said (Eds.), Educational Issues, Research and Policies (pp.113-128). Johor: UTM Press.

Nor, F. (2013). Epistemologi Saintifik Guru dan Pelajar Terhadap Mata Pelajaran Fizik (Master of education, Universiti Teknologi Malaysia, Skudai).

Paulsen, M. B., \& Wells, C. T. (1998). Domain Differences in the Epistemological Beliefs of College Students. Research in Higher Education, 39(4), 365-384. http://dx.doi.org/10.1023/A:1018785219220

Peer, J., \& Atputhasamy, L. (2005). Students' Epistemological Beliefs about Science: The Impact of School Science Experience. Journal of Science and Mathematics Education in S.E. Asia, 28(2), 81-95.

Phang, F. A., Ali, M. B., Mohd-Ghazali, N., Puteh, M., Bakar, M. N., Ahamd-Zanzali, N. A., . . Mohtar, L. E. (2013). Engineering Elements in School Science and Mathematics. Research in Engineering Education Symposium (REES 2013), Putrajaya, Malaysia on 4-6 July 2013. http://dx.doi.org/10.1109/educon.2011.5773115

Phang, F. A., Mohamad, B. A., Bakar, M. N., Zanzali, N. A. A., Rahman, N. F. A., Mohtar, L. E., .. Puteh, M. 
(2011). Engineering Elements Profile among First- and Final-Year Engineering Students in Malaysia. In M. E. Auer, A. Y. Al-Zoubi, \& E. Tovar (Eds.). 2011 IEEE Global Engineering Education Conference (EDUCON).

Radhakrishna, R. B. (2007). Tips for Developing and Testing Questionnaires/Instruments. Journal of Extension, $45(1)$.

Samarapungavan, A., Westby, E. L., \& Bodner, G. M. (2006). Contextual Epistemic Development in Science: A Comparison of Chemistry Students and Research Chemists. Science Education, 90(3), 468-495. http://dx.doi.org/10.1002/sce.20111

Sandoval, W. A. (2005). Understanding Students' Practical Epistemologies and Their Influence on Learning through Inquiry. Science Education, 89(4), 634-656. http://dx.doi.org/10.1002/sce.20065

Schommer-Aikins, M. (2004). Explaining the Epistemological Belief System: Introducing the Embedded Systemic Model and Coordinated Research Approach. Educational Psychologist, 39(1), 19-29. http://dx.doi.org/10.1207/s15326985ep3901_3

Smith, C. L., \& Wenk, L. (2006). Relations among Three Aspects of First-Year College Students' Epistemologies of Science. Journal of Research in Science Teaching, 43(8), 747-785. http://dx.doi.org/10.1002/tea.20113

Solomon, J., Scott, L., \& Duveen, J. (1996). Large Scale Exploration of Pupils' Understanding of the Nature of $\begin{array}{llll}\text { Science. } \quad \text { Science } & \text { 8ducation, } & \text { 494-508. }\end{array}$ http://dx.doi.org/10.1002/(SICI)1098-237X(199609)80:5<493::AID-SCE1>3.0.CO;2-6

Stathopoulou, C., \& Vosniadou, S. (2007). Exploring the Relationhip between Physics-related Epistemological Beliefs and Physics Understanding. Contemporary Educational Psychology, 32(3), $255-281$. http://dx.doi.org/10.1016/j.cedpsych.2005.12.002

Takayoshi, F., Piti, L., \& Phillips, B. J. (2012). Thai University Students' Scientific Epistemic Beliefs: Relationships with Past Learning Experiences. Procedia-Social and Behavioral Sciences, 69, 187-196. http://dx.doi.org/10.1016/j.sbspro.2012.11.398

The Malaysian Insider. (2012). Education Ministry forms committee to boost science student numbers. Retrieved September 24, 2013, from http://www.themalaysianinsider.com/malaysia/article/education-ministry-formscommittee-to-boost-science-student-numbers

Trautwein, U., \& Ludtke, O. (2007). Epistemological Beliefs, School Achievement, and College Major: A Large-Scale Longitudinal Study on the Impact of Certainty Beliefs. Contemporary Educational Psychology, 32, 348-366. http://dx.doi.org/10.1016/j.cedpsych.2005.11.003

\section{Copyrights}

Copyright for this article is retained by the author(s), with first publication rights granted to the journal.

This is an open-access article distributed under the terms and conditions of the Creative Commons Attribution license (http://creativecommons.org/licenses/by/3.0/). 